\title{
Terraced Landforms Onshore and Offshore the Cilento Promontory (South-Eastern Tyrrhenian Margin) and Their Significance as Quaternary Records of Sea Level Changes
}

\author{
Alessandra Savini ${ }^{1,2}\left(\mathbb{D}\right.$, Valentina Alice Bracchi ${ }^{1} \mathbb{D}$, Antonella Cammarosano ${ }^{3}$, Micla Pennetta ${ }^{3, *(D)}$ \\ and Filippo Russo 4 (D) \\ 1 Department of Earth and Environmental Sciences, University of Milano Bicocca (DISAT), 20126 Milan, Italy; \\ alessandra.savini@unimib.it (A.S.); valentina.bracchi@unimib.it (V.A.B.) \\ 2 CoNISMa, Local Research Unit, University of Milano Bicocca, 20126 Milan, Italy \\ Independent Researcher, 80138 Naples, Italy; anto.camm@hotmail.it \\ 4 Dipartimento di Scienze e Tecnologie, Università del Sannio, 82100 Benevento, Italy; filrusso@unisannio.it \\ * Correspondence: micla.pennetta@gmail.com
}

check for updates

Citation: Savini, A.; Bracchi, V.A.; Cammarosano, A.; Pennetta, M.; Russo, F. Terraced Landforms Onshore and Offshore the Cilento Promontory (South-Eastern Tyrrhenian Margin) and Their Significance as Quaternary Records of Sea Level Changes. Water 2021, 13, 566. https://doi.org/10.3390/w 13040566

Academic Editor: Giorgio Anfuso

Received: 31 December 2020

Accepted: 17 February 2021

Published: 23 February 2021

Publisher's Note: MDPI stays neutral with regard to jurisdictional claims in published maps and institutional affiliations.

Copyright: (C) 2021 by the authors. Licensee MDPI, Basel, Switzerland. This article is an open access article distributed under the terms and conditions of the Creative Commons Attribution (CC BY) license (https:/ / creativecommons.org/licenses/by/ $4.0 /)$.

\begin{abstract}
Climate change and tectonic uplift are the dominant forcing mechanisms responsible for the formation of long and narrow terraced landforms in a variety of geomorphic settings; and marine terraces are largely used to reconstruct the Quaternary glacial and interglacial climates. Along the Mediterranean coast, a considerable number of popular scientific articles have acknowledged a range of marine terraces in the form of low-relief surfaces resulting from the combined effects of tectonic uplift and eustatic sea-level fluctuations, as relevant geomorphological indicators of past sea-level high-stands. With the exception of a few recent studies on the significance of submarine depositional terraces (SDT), submerged terraced landforms have been less investigated. By integrating different marine and terrestrial datasets, our work brings together and re-examines numerous terraced landforms that typify the Cilento Promontory and its offshore region. In this area, studies since the 1960s have allowed the recognition of well-defined Middle to Upper Pleistocene marine terraces on land, while only a few studies have investigated the occurrences of late Pleistocene SDT. Furthermore, to date, no studies have consistently integrated findings. For our work, we correlated major evidence of emerged and submarine terraced landforms in order to support an improved understanding of the tectono-geomorphological evolution of the Cilento Promontory and to further clarify the geomorphological significance of submerged terraces.
\end{abstract}

Keywords: marine terraces; submarine geomorphology; coastal geomorphology; sea level oscillation; Tyrrhenian margin

\section{Introduction}

A terraced landform is any relatively flat horizontal or gently inclined surface bounded by a steeper ascending slope on one side and a steeper descending slope on the opposite side $[1,2]$. Terraces can be formed in many ways and in different geologic and environmental settings. In geomorphology, tectonic uplift and climate change are the dominant forcing mechanisms responsible for the formation of long and narrow terraced landforms. Resulting terraces can, therefore, be used for studying variations in tectonic, climate, and erosion, and for investigating how processes have interacted in the past and how they currently interact. The recognition of late Pleistocene uplifted coral platforms as indicators of past sea levels (i.e., reef terraces) was, for example, a significant finding in sea-level research [3]. Terrestrial, fluvial-glacial counterpart [4], coral reef terraces [3], and marine terraces $[5,6]$ have been (and still are) largely used for reconstructing Quaternary glacial and interglacial climates. Where tectonic uplift considerably impacts coastal regions, sub-aerial marine terraces clearly document high-stands of sea level during interglacial stages [6], 
alternating with low levels during glacial stages. In temperate regions, Pirazzoli [7] noted "marine-cut" terraces (or shore platforms) resulting from marine erosion and "marinebuilt" terraces formed by shallow-water and slightly emerged accumulations of materials removed by shore erosion. Along the Mediterranean coast, a range of sub-aerial marine terraces have been acknowledged to be relevant geomorphological indicators of past sealevel highstands (see [8] among other references). The study of Pirazzoli [7] has even allowed the definition of still popular marine stratotypes, outlining the first Quaternary chronostratigraphy (i.e., Calabrian, Emilian, Sicilian, Milazzian and Tyrrhenian for the Pleistocene, and Versilian for the Holocene). Although their work has been revised and refined, the chronostratigraphy is still used in gray literature and open discussions. The geomorphological significance of submerged terraced landforms [9-14], as evidence of Quaternary sea-level variations, has been less investigated and has only recently gained attention [15], thanks to advances in seafloor mapping techniques [16] and the resulting recognition of Submarine Depositional Terraces (SDT) (defined as sedimentary bodies with a clinostratified internal structure and a prograding growth towards the sea [17-21]). Minor studies have investigated the possible erosive nature of submerged terraced landforms formed on bedrock outcropping on the shelf and their relationship to sea-level oscillations, among them Bilbao-Lasa et al. [22]. Additionally, by taking into account both emerged and submerged terraces, a few investigations have integrated their findings to support an improved understanding of the tectono-geomorphological evolution of coastal areas and the physiography of the margin $[15,23]$, as we have undertaken in our work for the Cilento Promontory.

In this region, systematic studies since the 1960s [24-34] have determined well-defined Middle to Upper Pleistocene marine terraces on land. The submarine sector was the subject of minor research during the 1990s. Among such studies, Trincardi and Field [35] investigated the origin and forming mechanisms of remnants of late Pleistocene prograded coastal deposits, locally preserved on the middle and outer portions of the shelf.

\section{The Cilento Promontory and Its Offshore: Geological Setting and Stratigraphic Framework}

The coastal area of the Cilento region (Southern Italy) (Figure 1), included between Agropoli and Pioppi, represents the western end of one of the most important periTyrrhenian, morpho-structures belonging to the Campano-Lucano arch of the southern Apennine orogenic thrust system. Compressive tectonogenesis and structuring, initiated in the lower Miocene, appear to have ended in the Lower Pleistocene [29,36-40], through displacement of the Mesozoic-Tertiary bedrock of the Cilento coast during major Quaternary (Lower to Middle Pleistocene) tectonic activity [41-43]. The complex lithogenic history of the Cilento region has thus been shaped by numerous tectono-sedimentary events and orogenic shifts [44] that today allow us to distinguish different lithostratigraphic units outcropping along the coastline (Figure 1). Both siliciclastic and calcareous units outcrop on the Cilento Promontory. Siliciclastic units are primarily represented by the Cilento Flysch Unit [45,46] or Cilento Flysch Group "Auct" [41,42] that dominates in the north-western sector, and secondarily by the Ligurian and Northern Calabrese Auct tectonic units. Such units are often indicated as the "Internidi" [42,43] (Figure 1), the highest structural tectonic unit (thickness $1300 \mathrm{~m}$ ) that emerges for a few hundred meters in the central-southern portion of the promontory. Calcareous bedrock outcrops on the south-eastern sector of the Cilento region within the Monte Bulgheria Unit [47]. The general structural setting is dominated by low-angle overthrust surfaces that are clipped and folded by subvertical transcurrent and extensional surfaces with a variable orientation from NW-SE to E-W. The Internidi have been described as tectonic overlap on calcareous units. However, such overlap is sometimes reworked and masked by recent tectonics that are responsible for major displacements that caused carbonate uplift and relief inversion. Indeed, all along the Cilento Promontory the highest peaks are formed by carbonate units, while the most erodible siliciclastic units are found in places only preserved along valleys and on morphological and structural lows [48]. 


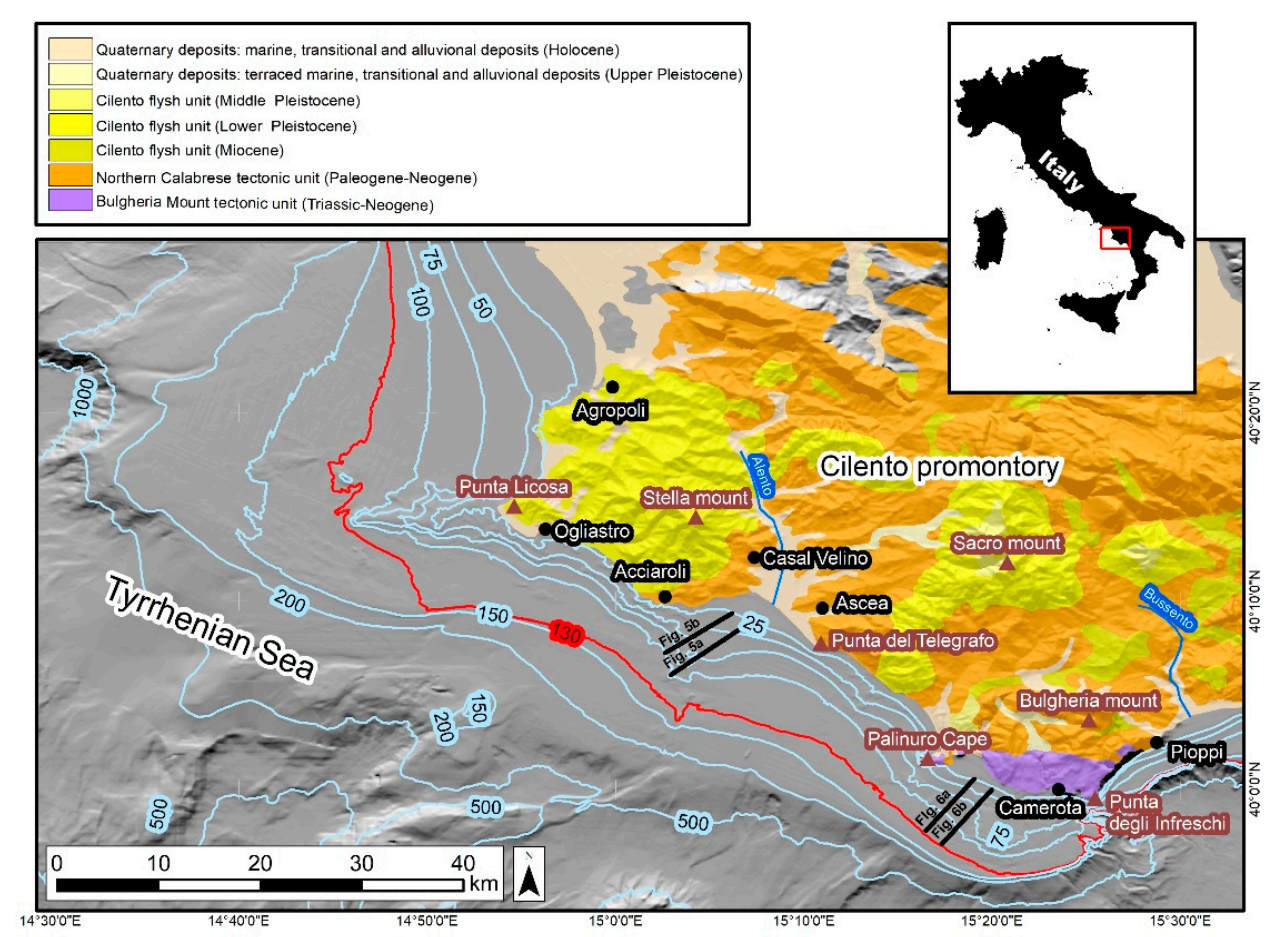

Figure 1. The study area. The on-land portion of the Cilento Promontory is represented by a schematic geological map of the Cilento region (The map was adapted from a geological map containing thematic elements and underwater landscapes at a 1:110,000 scale) overlaid on a Digital Elevation Model (DEM) adapted from Campania Region Technical Cartography at a 1:5000 scale. Isobaths and offshore shaded relief were obtained from the EMODNET portal (https: / www.emodnet-bathymetry. eu/, accessed on15 February 2021).

Quaternary deposits formed by marine, transitional, or alluvial sediments, where preserved, are found in angular unconformity on the described bedrock. Outcrops of coastal marine sediments (biocalcarenites, fossiliferous beaches and aeolian sands), often associated with typical forms of marine abrasion and bioerosion (shore platforms, fossil eroded notches, "Lithophaga" holes, etc.), are found in very small and discontinuous terraced strips (at various heights between $2 \mathrm{~m}$ and $300 \mathrm{~m}$ above sea level (a.s.l.)) along the entire Cilento coastal zone. Such deposits, sometimes alternating with "colluvial", pyroclastics, and paleosoils, have been the subject of careful and systematic studies since the 1960s [24-34], allowing chronological attribution to the Middle and Upper Pleistocene.

Offshore, the shelf of the eastern Tyrrhenian Margin lies between the uplifting Apennine chain on land and the Tyrrhenian offshore basin that has been subsiding at a rate of $1 \mathrm{~mm} / \mathrm{yr}$ since the end of the Lower Pleistocene [49]. Due to the multifaceted tectonic history determined by the opening of the Tyrrhenian Sea, that is also associated with limited Plio-Quaternary sedimentation at places interrupted on the shelf by bedrock outcrops [48], the seabed topography is extremely complex. Seismic data has revealed a deformed acoustic basement, displaced by quaternary faults with very sharp and steep scarps similar to the ones detected on land. The continental shelf is wider in the northern portion, extending for almost $30 \mathrm{~km}$ to the north of Punta Licosa [50], and delimited seaward by an uncertain shelf break, from 180 to more than $200 \mathrm{~m}$ in depth. To the south, continental shelf width is reduced to less than $10 \mathrm{~km}$, and in offshore Acciaroli the shelf break is sharper and is located at a water depth (w.d.) of roughly $130 \mathrm{~m}$. In the southern sector (Figure 1), the shelf further narrows to $6 \mathrm{~km}$ and a transition between the shelf and the slope is evident, but located at variable depth, gradually decreasing from $140 \mathrm{~m}$ off Punta del Telegrafo to $130 \mathrm{~m}$ in .w.d. offshore of the south-eastern corner of the promontory, where the upper continental slope is much steeper and likely coincident with a tectonic escarpment [51-53]. Different sub-horizontal surfaces bounded by fairly continuous and slightly sinuous escarpments have also been 
determined on the shelf. They have been interpreted as submarine terraces $[48,54,55]$ that formed by local and prolonged low sea level stationing, occurring between the regression of the Last Glacial Maximum (LGM) and subsequent rapid post-glacial sea-level rise (i.e., the Flandrian Transgression). Only a few of the submarine terraced landforms located near sea level ( $8 \mathrm{~m}$ to $12 \mathrm{~m}$ below sea level (b.s.l.)) are ascribed to Marine oxygen Isotopic Stage (MIS) $5[32,56,57]$, corresponding to the Last Interglacial period.

The continental slope is marked by depressions and topographic highs of variable dimension, down to a depth of $1600 \mathrm{~m}$. Numerous escarpments document the existence of simple to complex landslide scars, testifying to the dominant role of mass-wasting phenomena in shaping the continental margin. A complex tectonic framework of bedrock is also still visible along the slope, where it has created local, intra-slope reliefs and marked tectonic lineaments [53-55].

\section{Data and Methods}

Our study was driven by the collection of major evidences of terraced landforms, both on land and in offshore areas of the Cilento Promontory coastal zone, recovered from scientific literature and detected on available Digital Elevation Models (DEM-i.e., Emodnet database—https:/ / portal.emodnet-bathymetry.eu/ (accessed on 20 February 2021)—grid cell size $50 \times 50 \mathrm{~m}$ and Magic project: http:/ / dati.protezionecivile.it/geoportalDPC/rest/ document\#MagicFoglio10/ (accessed on 20 February 2021) — grid cell size $50 \times 50 \mathrm{~m}$ ) for the offshore sector. Submarine terraced landforms were also manually and automatically detected by applying a geomorphometric analysis performed using Spatial Analysis Tool available in ArcGis ${ }^{\circledR}$. All terraced landforms were then collected in a proper database by including information regarding dating, altitude or depth, and references (Tables 1 and 2). Landform spatial and temporal distributions were analysed in order to detect the role of associated bedrock and the structural framework in controlling distributions and geomorphological differentiation.

Terraces were grouped according to lithostratigraphic units of the corresponding bedrock (i.e., siliciclastic or calcareous), namely, from North to South: (1) Cilento Flysch and "Internidi" Units; and (2) the Carbonate Unit of Mount Bulgheria, with outcroppings regions located in the area surrounding Palinuro (Palinuro Cape, Mingardo river mouth and Camerota) on the southern coast of the Cilento Promontory (Figure 1).

Study of the offshore region was also supported by the availability of high resolution seismic data collected using a GeoAcoustic GEOCHIRPII (GeoAcoustic Limited, Shuttleworth Close, Doncaster, UK) Subbottom Profiler System (SBP) in 2003, between 10 and $130 \mathrm{~m}$ in w.d., as well as by results obtained from a sedimentological analysis performed on 16 gravity cores and 32 grab samples, as described in [58]. An interpretation of depositional and erosional processes, as detected from a seismo-stratigraphic analysis, was performed using the concepts of sequence stratigraphy $[59,60]$.

\subsection{On Land Terraced Landforms}

To understand traces of described ancient marine deposits and sea-level markers, background knowledge of the study area was obtained from an extensive literature review $[24,26,28,30-34,61-69]$, and a field survey. Table 1 provides on-land terraced landforms according to their altitude and dating (as ascribed in the scientific literature).

\subsection{Offshore Terraced Landforms}

Background knowledge for the submarine sector of the study area was obtained by collecting public bathymetry (EMODnet portal) and high-resolution seismic data, as described in Savini et al. [58], along with analogous remote data and evidence of direct observations as reported in the scientific literature [32,48,50,54-57]. To detect flat surfaces, basic geomorphometric analysis were performed in ArcGIS ${ }^{\circledR}$. All areas with a slope value $\leq 1$ and confined by a marked break of slope (according to [1]) were segmented and converted in polygons (Figure 2B). 
Table 1. List, reported dating in the scientific literature, altitude, and referenced literature for on-land terraced landforms.

\begin{tabular}{|c|c|c|c|c|}
\hline & Geological Unit & Dating & Altitude (m) & Notes and References \\
\hline \multirow{7}{*}{ 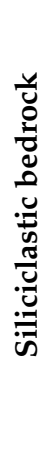 } & \multirow{6}{*}{$\begin{array}{l}\text { Cilento Flysch } \\
\text { Unit }\end{array}$} & Lower Pleistocene & $?$ & $\begin{array}{c}\text { No clear evidences } \\
{[64]}\end{array}$ \\
\hline & & Middle Pleistocene (MIS 9) & 60 & [30] \\
\hline & & Middle Pleistocene (MIS 7) & 25 & {$[30,67]$} \\
\hline & & Upper Pleistocene (MIS 5e) & $6.5-10$ & {$[28,30,67]$} \\
\hline & & Upper Pleistocene (MIS 5c) & $4-5$ & {$[30,66,67]$} \\
\hline & & Upper Pleistocene (MIS 5a) & $1.5 ?$ & {$[30,66,67]$} \\
\hline & $\begin{array}{l}\text { Cilento Group and } \\
\text { Internidi Units }\end{array}$ & Upper Pleistocene (MIS 5e) & 6 & $\begin{array}{c}\text { Beach-ridge deposits } \\
{[24,28,65]}\end{array}$ \\
\hline \multirow{15}{*}{ 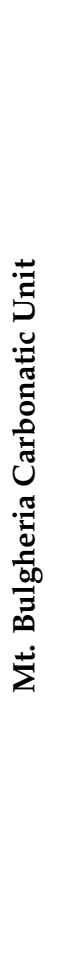 } & \multirow{7}{*}{ Palinuro Cape } & Lower Pleistocene & 350 & {$[29,32,64]$} \\
\hline & & Middle Pleistocene & $170-180$ & [32] \\
\hline & & Middle Pleistocene & $130-140$ & [32] \\
\hline & & Middle Pleistocene & $75-65$ & [32] \\
\hline & & Middle Pleistocene & 50 & [32] \\
\hline & & Upper Pleistocene & $8-7$ & {$[32]$} \\
\hline & & Upper Pleistocene & $3-2$ & [32] \\
\hline & \multirow{3}{*}{ Mingardo river } & Middle Pleistocene & $\begin{array}{l}\text { Many orders } \\
75-15\end{array}$ & [34] \\
\hline & & Upper Pleistocene & $12-10$ & [34] \\
\hline & & Upper Pleistocene & $4-3$ & [34] \\
\hline & \multirow{5}{*}{ Camerota } & Lower Pleistocene & $0-350$ & {$[29,30,32,64]$} \\
\hline & & Middle Pleistocene & 50-200 & [68] \\
\hline & & Upper Pleistocene & 15 & {$[32,34]$} \\
\hline & & Upper Pleistocene & $12-10$ & {$[32,34,69]$} \\
\hline & & Upper Pleistocene (MIS 5) & $\begin{array}{l}8.5-8 \\
7.5-5 \\
4.5-4 \\
3.5-3\end{array}$ & {$[31,32,34]$} \\
\hline
\end{tabular}

?: Uncertain value or not confirmed by consistent data.

Table 2. List, reported dating in the scientific literature, depth, and referenced literature for offshore terraced landforms. The table takes into account terraces cited in the scientific literature. The correspondence with terraces detected by geomorphometric analysis is reported in the last column on the right.

\begin{tabular}{|c|c|c|c|c|}
\hline Geological Unit & Dating & Depth (m) & $\begin{array}{l}\text { Notes and } \\
\text { References }\end{array}$ & $\begin{array}{c}\text { Correspondence on } \\
\text { Slope Value }\end{array}$ \\
\hline \multirow{8}{*}{ 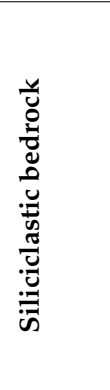 } & Upper Pleistocene & -8 & [55] & Not evident \\
\hline & Upper Pleistocene & $-10 / 14$ & [55] & Not evident \\
\hline & Upper Pleistocene & $-17 / 27$ & [55] & Yes $(-21 / 26)$ \\
\hline & Upper Pleistocene & $-43 / 50$ & [55] & Yes $(-47 / 52)$ \\
\hline & Upper Pleistocene & -86 & [48] & Yes $(-86)$ \\
\hline & Upper Pleistocene & -107 & [48] & Yes $(-108)$ \\
\hline & Upper Pleistocene (MIS 2) & -120 & [50] & Not evident \\
\hline & Upper Pleistocene (MIS 2) & -160 & [50] & Not verified \\
\hline
\end{tabular}


Table 2. Cont.

\begin{tabular}{|c|c|c|c|c|c|}
\hline \multicolumn{2}{|c|}{ Geological Unit } & Dating & Depth (m) & $\begin{array}{l}\text { Notes and } \\
\text { References }\end{array}$ & $\begin{array}{l}\text { Correspondence on } \\
\text { Slope Value }\end{array}$ \\
\hline 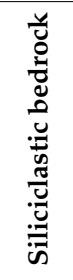 & 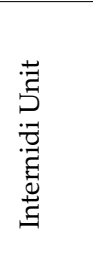 & $\begin{array}{l}\text { Flandrian } \\
\text { transgression }\end{array}$ & $-46 / 51$ & [58] & Yes $(-47 / 52)$ \\
\hline \multirow{4}{*}{ 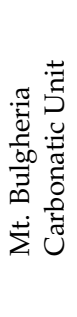 } & \multirow{4}{*}{ 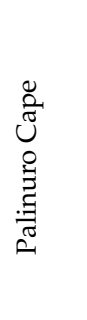 } & Upper Pleistocene & $-7 / 8$ & $\begin{array}{c}\text { Notches } \\
\text { [32] }\end{array}$ & Not evident \\
\hline & & Upper Pleistocene & $-12 / 14$ & $\begin{array}{l}\text { Wave-cut platform } \\
\text { [32] }\end{array}$ & Yes $(-12 / 21)$ \\
\hline & & $\begin{array}{l}\text { Upper Pleistocene } \\
\text { (MIS 3) }\end{array}$ & $-18 / 24$ & $\begin{array}{l}\text { Wave-cut platform } \\
\text { [32] }\end{array}$ & Not evident \\
\hline & & $\begin{array}{l}\text { Flandrian } \\
\text { transgression }\end{array}$ & $-44 / 46$ & $\begin{array}{c}\text { Notches } \\
\text { [32] }\end{array}$ & Not evident \\
\hline
\end{tabular}
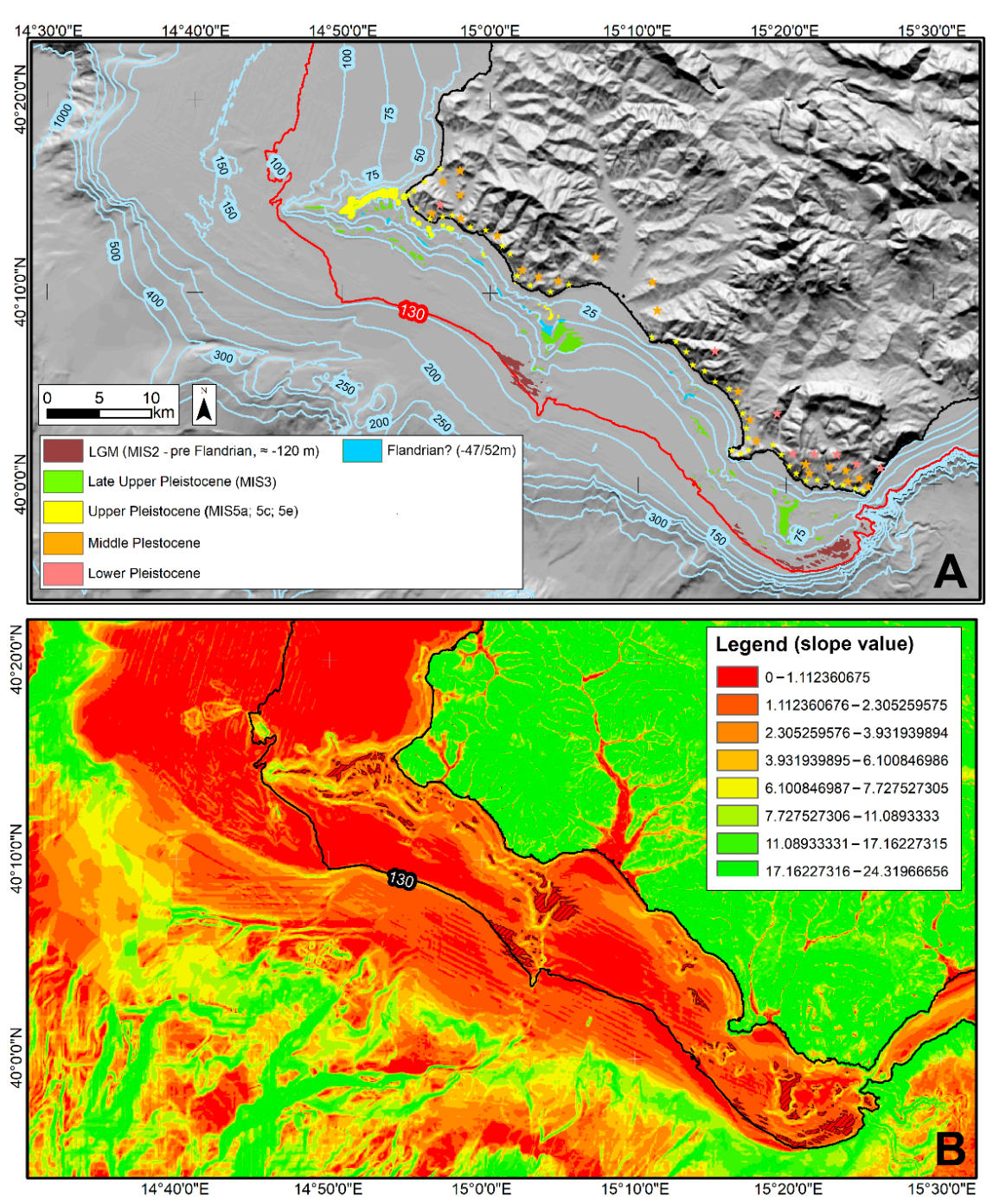

Figure 2. (A): A map of major terraced landforms detected on land and offshore in the Cilento Promontory, as reported in Tables 1 and 2, with the exception of the submarine depositional terraces (SDT) reported in [48,50]. (B): A slope map with red polygons indicating flat areas (slope $\leq 1$ ) delimited by marked ascending and descending breaks in slope. 


\section{Results}

\subsection{Terraced Landforms: Temporal and Spatial Distribution}

The presence of terraced landforms in the Cilento coastal area marked the emerged and submerged sectors (Tables 1 and 2). Scientific literature has documented at least seven orders of Pleistocene terraced surfaces on land (Table 1 and Figure 2), spanning from the Lower to Upper Pleistocene [32].

Offshore terraced landforms (Figure 2) were, instead, first detected using geomorphometric techniques (Figure 2B), then correlated with evidence in the scientific literature $[32,48,50,54-58]$, and then grouped according to depth range of occurrence (Figure 2A). For terraced surfaces deeper than $50 \mathrm{~m}$, we also refer to [50] and [48]. As discussed below, the distribution of both on-shore and off-shore terraced landforms was then resumed according to geological unit.

\subsubsection{Northern Cilento Group}

On-land five terraced surfaces have been identified (Table 1 and Figure 2). Two were from the Middle Pleistocene (MIS 7 and 9) with clear evidence of uplift, apparently sealed by Upper Pleistocene deposits. The remaining three were from the Upper Pleistocene (MIS 5a, MIS 5c and MIS 5e), with no significant contribution from tectonics.

The submerged sector is typified by prolongation towards the sea of the "Punta Licosa" Promontory (Figures 1 and 2) that (1) provides an EW aligned spur formed by an outcrop of the acoustic basement that rests over more than $16 \mathrm{~km}^{2}$, between 25 and $80 \mathrm{~m}$ of w.d.; (2) likely originated from the Cilento Group synorogenic unit (or "Flysch del Cilento") and; (3) was bounded by direct faults. The spur rises from the surrounding seafloor through several sharp escarpments bounded by flat terraced surfaces (Figures 2 and 3 ).

According to the scientific literature, terraces are positioned at $-8 \mathrm{~m},-10 / 14 \mathrm{~m}$, $-17 / 27 \mathrm{~m}$, and $-43 / 50 \mathrm{~m}$ and reportedly range from MIS $5 \mathrm{a}$ or $5 \mathrm{c}$ up to MIS $3[50,55,57,66]$. A performed geomorphometric analysis distinctly outlined the marked stepped profile of the Licosa spur and several submarine terraces (slope $\leq 1$ ), with a prevalence at $-21 / 26 \mathrm{~m}$, $-47 / 52 \mathrm{~m}$, and $-76 / 86 \mathrm{~m}$, having consistent lateral continuity (especially toward the south and for depth intervals of $-21 / 26 \mathrm{~m}$ and $-47 / 52 \mathrm{~m}$ ) (Figures $3 \mathrm{~A}$ and 4 ), were located. Small scale landforms resembling tension fractures at the crowning areas of modest landslides are frequent on the southern slope of the spur [55], an isolated group of terraced surfaces downward of small landslide scars was identified at $-28 / 30 \mathrm{~m}$ (Figure 4). Ferraro et al. [48] detected additional terraced landforms at $86 \mathrm{~m}$ and even deeper at $107 \mathrm{~m}$ of w.d., both of an erosional origin, and indicated that the terraces formed at the outcrop of the acoustic basement. Further offshore, biogenic coarse sandy depositional bodies, bounded at their top by a ravinement surface, were described at $120 \mathrm{~m}$ and $160 \mathrm{~m}$ in w.d. Such bodies are developed over more than $20 \mathrm{~km}$ along-slope [48]. A small fragment of "Arctica islandica" (Linneo, 1767) was also recovered from a core sample ([48]; Pennetta pers. com.) allowing attribution of their formation to the last low-stand period (i.e., MIS 2). Trincardi and Field [50] also reported the occurrence of depositional bodies in the form of shelf-margin deposits, truncated at their tops by an outer-shelf ravinement surface at $-150 / 160 \mathrm{~m}$. The shelf-margin is reported to occur at $-200 \mathrm{~m}$ in w.d. (Figures 1 and 2) (i.e., deeper than the sea level low-stand reported for the Last Glacial Maximum (namely $120 \mathrm{~m}$ in w.d.). Marani et al. [70] indicated that these sandy bodies appear to have formed in a shallow ( $<30 \mathrm{~m}$ deep) marine setting. This evidence, together with the detection of an outer limit for the ravinement surface generated by the post-Würmian Transgression at a deeper depth than the one reported for the eustatic minimum (i.e., $120 \mathrm{~m}$ ), suggests that the outer continental shelf has been subject to important (tectonic) subsidence phenomena over the Holocene. Considering Mediterranean wave-base level in the order of 10/15 m [71], we speculate that the subsidence rate reported for the Tyrrhenian sea by Kastens et al. [49] (i.e., $1 \mathrm{~mm} / \mathrm{yr}$.) allowed a merger of the geodynamics of the outer portion of the continental shelf with the structural system that currently controls evolution of the Tyrrhenian basin. 

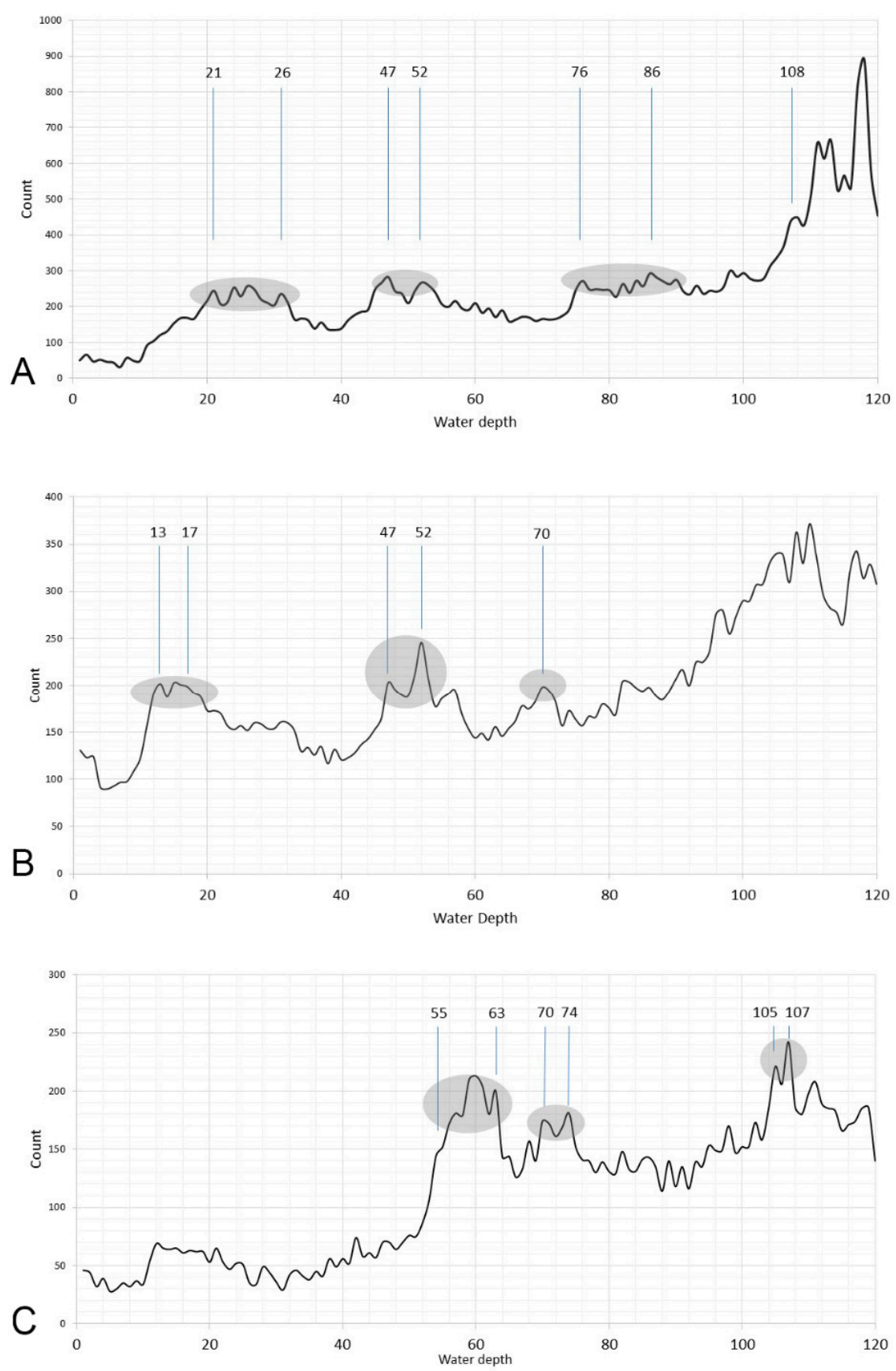

Figure 3. Histograms of depth values (depth range 0-120 $\mathrm{m}$ in w.d.) for the offshore areas of Northern Cilento group (A); Cilento Group and Internidi Units (B); and Southern Bulgheria Mount (C). The gray ellipses show the depth ranges that, on the map, are clearly delimited by sharp breaks in slope.

\subsubsection{Cilento Group and Internidi Units}

The central continental coastal area of Cilento, between Acciaroli and Palinuro, is essentially composed by deformed units of Mesozoic-Tertiary Bedrock (members of the Cilento Group and Internidi Units) covered in angular discordance by Quaternary alluvial and coastal deposits. In places, coastal deposits represent the filling of localized morphotectonic depressions of actual alluvial (i.e., the plain of the Alento River) and coastal (i.e., plain of Casalvelino-Ascea-Figure 1) plains consisting of fluvial sediments, dune and beach-ridge deposits sometimes covered by continental colluviums, and slope debris. Marine beach-ridge deposits, emerging up to six $\mathrm{m}$ a.s.l. along the coast at Ogliastro [28] and Acciaroli [24], have been attributed to the Upper Pleistocene (Table 1 and Figure 2). In 
this sector, no deposits or forms have been found that can be attributed, with certainty, to the Lower or Middle Pleistocene (Figure 2).

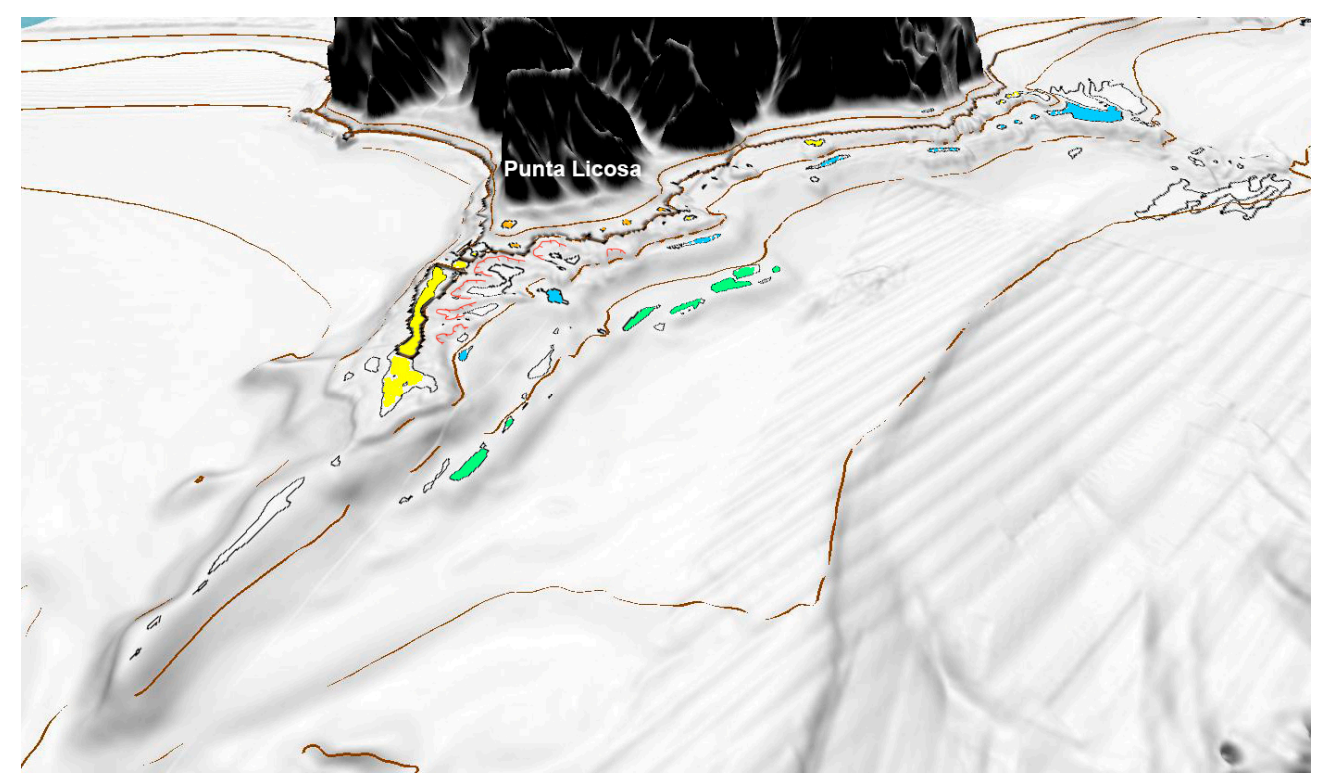

Figure 4. A 3D view of the seaward prolongation of the Punta Licosa Promontory, with polygons detected by geomorphometric analysis, representing terraced landforms according to [1] and distinguished in different colors according to depth range (yellow: 21/26 m; light blue: 47/52 m; green: 76/86 m). Small-scale landslide scars are also mapped (red lines) on the southern side of the submerged Punta Licosa spur. The Digital Terrain Model data products used to provide the 3D view have been derived from http:/ / dati.protezionecivile.it/geoportalDPC/rest/document\#MagicFoglio10 (accessed on 20 February 2021).

Offshore, the morpho-structural depression, marked on land by the coastal and alluvial plain of Casal Velino-Ascea (Figure 1), is filled by sandy-silty deposits [58] over almost all of the central and southern continental shelf, in continuity with terrestrial physiography (Figure 2). The depression is confined to the north by the outcrop of the acoustic basement, that forms a southward-elongated ridge offshore Acciaroli, interrupted at the shelf break (Figures 1 and 2). The coupling of bathymetric and high-resolution seismic data clearly indicates marked terraced landforms along the ridge. Terraced landforms are particularly evident at a depth interval between 47 and $52 \mathrm{~m}$ (Figure 3B), in the form of an erosional surface (wave-cut platforms [58]) sculpted within the acoustic basement (i.e., bedrock, Figure 5A). As shown by the marine DEM and the associated slope value (Figure 2B), the terraced landforms are still in continuity with those detected northward at Punta Licosa, especially for the depth range $47 / 52 \mathrm{~m}$. A north-south elongated depositional body (with a lenticular section formed by poorly defined sloping depositional units that resemble shoreface clinoforms [58]) rest at $55 \mathrm{~m}$ in w.d. in overlap above the southeastern edge of the acoustic basement that outcrops to the south of Acciaroli (Figure 5). According to sediment composition reported in [58,72], the depositional body likely formed in a shallow $(<10 \mathrm{~m}$ deep) marine setting. Since an older origin would have resulted in aerial exposure due to sea level drop during the LGM, the absence of an obvious erosional surface at the top of the deposit and partial burial towards the sea due to the high-stand drape (Figure 5B), warrants ascription to the transgression that followed MIS 2.

\subsubsection{Southern Bulgheria Mount}

On land, the best-preserved Quaternary landforms and deposits of the Cilento Promontory are found in Palinuro Cape (the Monte Bulgheria Carbonatic Unit), an area intensively studied and well described within the scientific literature [32]. The oldest evidence of flat eroded surfaces within the region are dated to the Upper and Lower Pliocene. Land- 
forms are found at altitudes between 1200 and $400 \mathrm{~m}$ a.s.l. and have been associated with sub-aerial surfaces of fluvial-karst erosion, although some authors do not exclude marine abrasion as a potential origin [69].
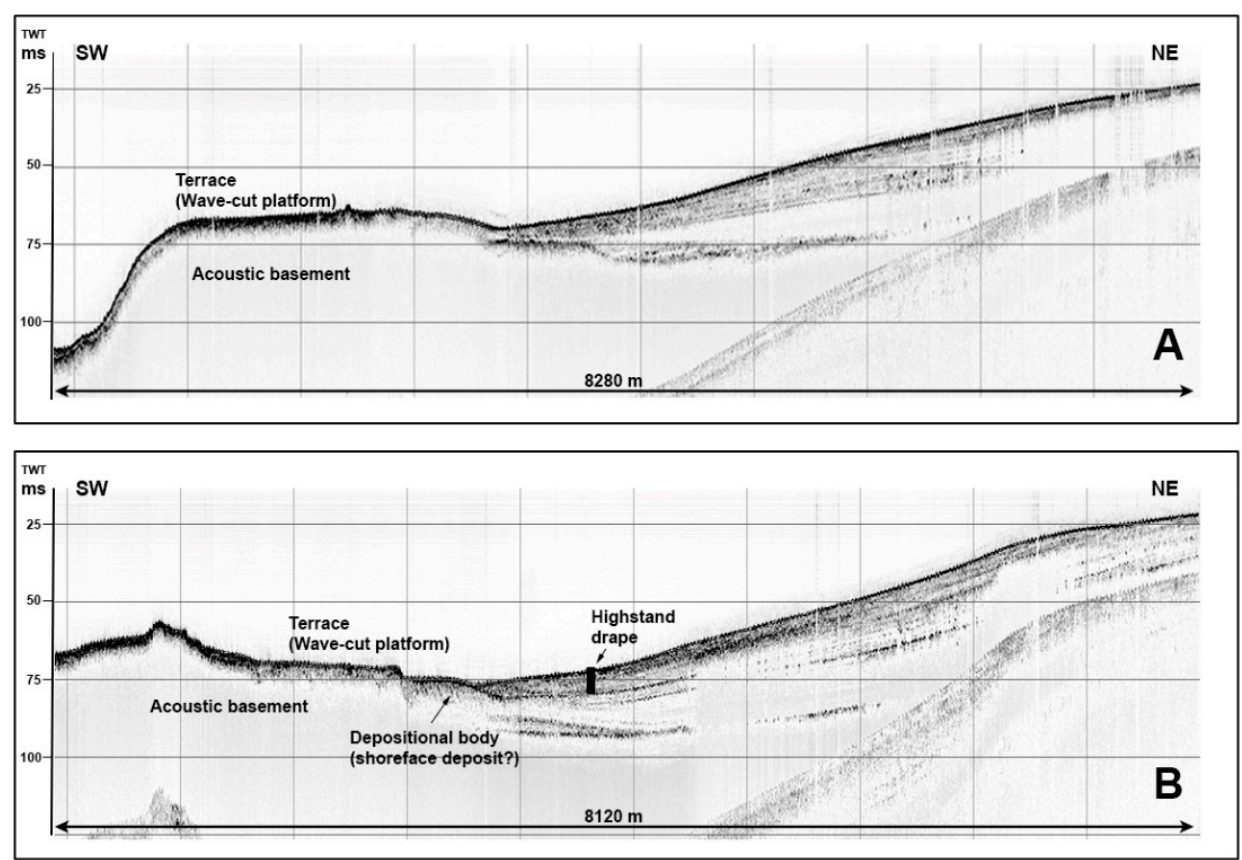

Figure 5. High-resolution seismic profiles acquired offshore Cilento Group and Internidi Units. See Figure 1 for location. (A) A submerged terraced landform (wave-cut platform) is visible at 47-51 $\mathrm{m}$ in w.d. (corresponding to 63/68 ms). (B) A submerged terraced landform (wave-cut platform) is visible at roughly $51 \mathrm{~m}$ in w.d. (corresponding to $68 \mathrm{~ms}$ ).

The oldest Pleistocene terrace outcrops around $300 \mathrm{~m}$ a.s.l. and corresponds to the Lower Pleistocene [64].

Overall, the area records several order of terraces positioned at variable altitudes that are not easily correlated to the Middle Pleistocene. Four order of terraces, at an altitude range between $20 \mathrm{~m}$ and $200 \mathrm{~m}$ a.s.l., have been ascribed to the Middle Pleistocene. Additionally, five orders of Middle Pleistocene marine abrasion terraces were carved along the coastal slopes at altitudes of 180/170 m, 140/130 m, $100 \mathrm{~m}, 75 / 65 \mathrm{~m}$, and $50 \mathrm{~m}$, for which important tectonization cannot be excluded.

Upper Pleistocene terraced surfaces outcrop continuously along the cost and they are located between $1.5 \mathrm{~m}$ and $10 \mathrm{~m}$ a.s.l. (Table 1). Two marine terraces located along a sea-cliff that marks the coastal area at $8 / 7 \mathrm{~m}$ and $3 / 2 \mathrm{~m}$ a.s.l., and beach-ridge deposits containing fragments of Thetystrombus latus Gmelin 1791 (=Strombus bubonius) are found at $3 / 2 \mathrm{~m}$ a.s.l. The location of these Upper Pleistocene landforms suggested a small (few meters) tectonic lowering of the area. In general, since good lateral continuity is preserved and since the terraces are quite well correlated, terraces created by Upper Pleistocene sea-level oscillations seem to document a relatively stable tectonic period [73].

As for the submarine portion between Palinuro Cape and Bulgheria Mount, four orders of submarine terraces, located at $7 / 8 \mathrm{~m}, 12 / 14 \mathrm{~m}, 18 / 24 \mathrm{~m}$, and $44 / 46 \mathrm{~m}$ in w.d., have been extensively described within the scientific literature [32]. Since they show evidence of subaerial erosion associated with a regressive period, the first two terraces were ascribed to the Last Interglacial (MIS5), or to an earlier period. Evidence of former sea-level positions at $7 / 8 \mathrm{~m}$ in w.d. have been attributed to MIS5a with good confidence.

Terraces detected in the form of wave-cut platforms at 18/24 $\mathrm{m}$ in w.d. were, instead, ascribed to the last phase of MIS3, which seems to be characterized by long stationing that occurred during the post-Last Interglacial regression [56]. According to Antonioli et al. [32], good conservation of the deposit and the absence of subaerial erosion for terraces located 
at 44/46 $\mathrm{m}$ in w.d. leads attribution to a lower standing period that occurred during the last, post glacial transgression (i.e., the Flandrian Transgression). Sparce terraces found at deeper depth were, in contrast, formed by depositional bodies and are ascribed to the last glacial low-stand period (MIS2). The geomorphometric analysis performed on the DEM detected quite large terraces at three main depth range: 55/63 m, 70/77 m, and 105/107 m. Seismic data well confirmed the erosional origin of mapped terraces located at 50/55 $\mathrm{m}$ in w.d. (Figure 6). Due to DEM resolution, which cannot resolve submarine terraces of small dimensions, many shallower terraces were likely difficult to detect.
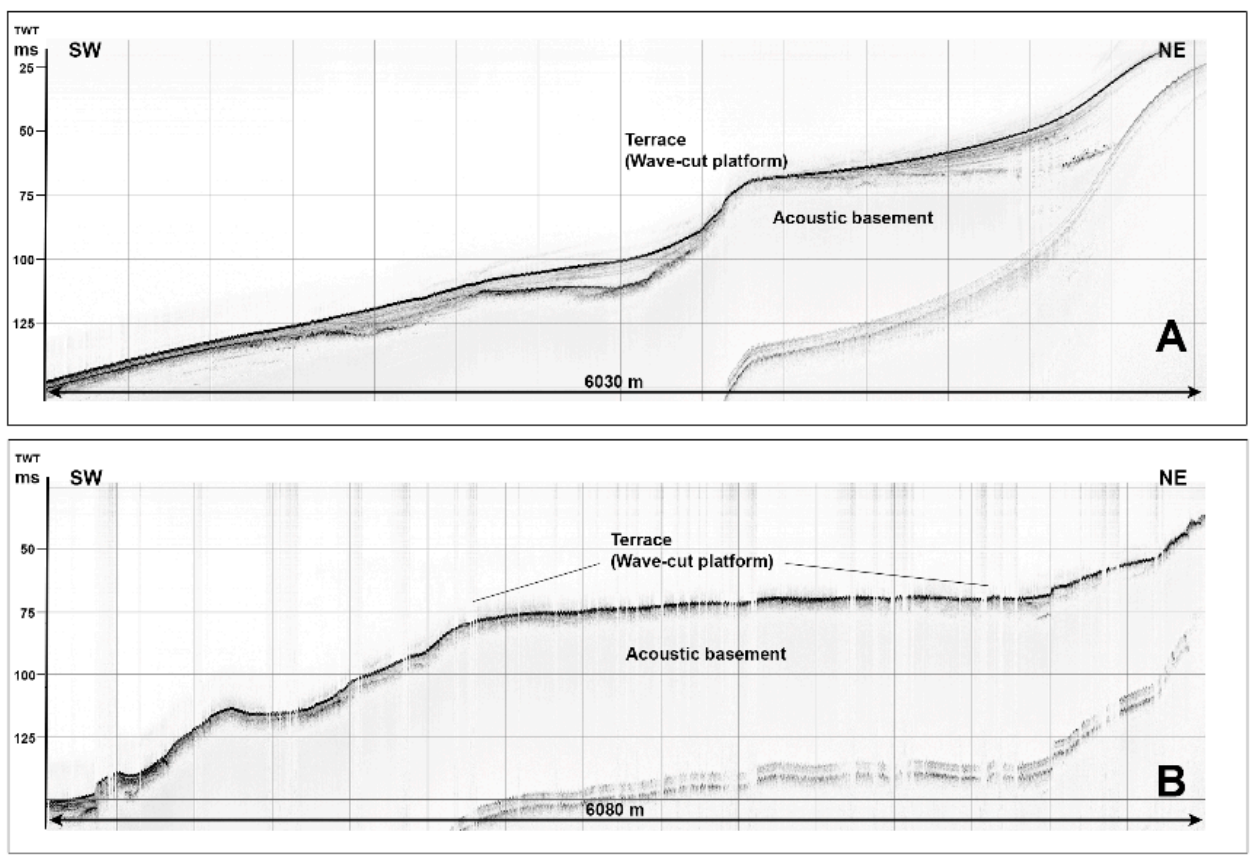

Figure 6. High-resolution seismic profiles acquired offshore Southern Bulgheria Mount.. See Figure 1 for location. (A) A submerged terraced landform (wave-cut platform) is visible at roughly $50 \mathrm{~m}$ in w.d. (corresponding to $67 \mathrm{~ms}$ ); (B) A submerged terraced landform (wave-cut platform) is visible between 51 and $55 \mathrm{~m}$ in w.d. (corresponding to 68/75 ms).

\section{Discussion}

Abundant evidence of former Quaternary sea-level stationing, in the form of terraced landforms, occurs on the Cilento Promontory from north to south and on its offshore counterpart. One of the first observations obtained by grouping various terraces according to their lithological unit was consequent variation in the degree of conservation of erosive forms created by former sea level positions (i.e., marine terraces of dominant erosional origin). Such forms were, indeed, better preserved when associated with carbonate rocks of the Mount Bulgheria Unit. Bedrock of terrigenous origin (Cilento Flysch and Internidi Units) hinders the conservation of Quaternary erosive landforms [26,74], that were smaller and poorly represented. On the Mount Bulgheria Unit, a more widespread and continuous conservation of the Quaternary deposits was evident, allowing plentiful geological and geomorphological information to be obtained for reconstructing the age and alternation of former sea-level positions [25,28,29,31,32,34,61,62].

From analyzed data, it appears that older terraces can be detected up to $300 \mathrm{~m}$ a.s.1. Several Lower and Middle Pleistocene terraces have been cataloged. However, the complex tectonic history of the region makes it difficult to perform accurate correlations, although focused dating could improve our understanding of the post-orogenic tectonic differentiation that typified the variuos uplifting rates of the Cilento Units. Additionally, some sector of the promontory were tectonically displaced upwards by approximately $400 \mathrm{~m}$ during the late Lower and the Middle Pleistocene. The Upper Pleistocene experienced reactivations, but on a smaller scale and were differentiated from north to south. 
A different Upper Pleistocene geodynamic behavior seems to characterize the offshore region where tectonic movements or relative stability, documented by the position of dated marine terraces on-land, are well correlated with the submarine sector for areas shallower than $120 / 130 \mathrm{~m}$ in w.d. In the offshore sector, the shallower orders of terraced landforms, likely generated as wave-cut shore-platforms, did not record relevant tectonic/vertical movements during the Upper Pleistocene. Since their position seems to be well correlated with former sea-level positions, as reported in the global mean sea-level curves (Figure 5), the result is in good agreement with documented research on land $[75,76]$. Seismic data additionally indicates that during the last period of sea level rise, a transgressive erosional surface (i.e., ravinement surface) formed in the area [50] and that its relationship to depositional bodies detected on the shelf critically improved constraints for ascribing the relative position of sea-level to detected submerged terraces. We gave considerable importance to the curve of isotopic stratigraphy in [77], and to other evidences reported for Holocene relative sea-level curves $[78,79]$, where a short stasis is reported for the rapid Flandrian Transgression between 45 and $40 \mathrm{~m}$ in w.d.. This depth range is close to some of the mapped offshore terraces in the form of a wave-cut shore platform (Table 2, Figures 2 and 3) and displays strong lateral continuity all along the offshore sector of the Cilento Promontory (Figures 2B and 4). In contrast, as speculated on the basis of relative sea-level fluctuations documented by low-stand depositional bodies that formed SDT at $160 \mathrm{~m}$ in w.d. [50], the outer shelf appears to have experienced an important tectonic subsidence.

Using all collected evidence, we observed that submarine terraced landforms offshore of the Cilento Promontory can be distinguished as erosional and depositional, respectively representing paleo wave-cut shore platforms (see [80] for a comprehensive definition and differentiation from marine terraces) and SDTs (as described in [9] and references therein). In our study area, terraced landform distinction is marked by the depths at which they occur (Figure 5). On the outer zone of the continental shelf, and especially in areas deeper than $120 \mathrm{~m}$ in w.d., SDTs have been described by Ferraro et al. [48] and have been interpreted by Trincardi and Field [50] as shelf-margin deposits, with a different configuration according to physiographic shelf-break depth during the last sea-level low-stand (i.e., MIS2). Shelf margin deposits particularly occur offshore of the Cilento Promontory where the physiographic shelf-break is deeper than the position of the low-stand shoreline of the Last Glacial Maximum (MIS2). Trincardi and Field [50] highlighted the absence of such deposits, where the shelf-break was close to the shoreline during MIS2. The different configuration of SDTs, located on the outer shelf (as described in [50]) and the concurrent deepening and widening of the physiographic shelf break toward the north, warrants a distinction between the two main morpho-structural elements forming the shelf, as follows:

- $\quad$ A shelf sensu stricto, extendeding from the coastline down to $130 \mathrm{~m}$ in w.d., where there is an almost continuous break in slope, that, south of the Cilento Promontory, is sharp and coincides with the physiographic shelf break (i.e., offshore Mount Bulgheria) that progressively leads to a slightly deeper and flat outer shelf toward the north (Figure 1).

- An outer shelf, particularly evident offshore of Punta Licosa from $130 \mathrm{~m}$ down to more than $200 \mathrm{~m}$ in w.d. (Figure 1).

The two morpho-structural elements seem to represent the components of a regional fault system. The system is defined by NW-SE and NNE-SSW lineaments, marking the core area that separates the uplifting morpho-structural high forming the Cilento Promontory on the margin (interposed between the coastal depressions of the Sele Plain-Salerno Gulf to the north and of the Policastro Gulf to the south-east), and the Tyrrhenian basin offshore. The offshore tyrrhenian basin has been subsiding at a rate of $1 \mathrm{~mm} / \mathrm{yr}$ since the end of the Lower Pleistocene [48] and from the Last Glacial Maximum until present could have been responsible for the lowering of the shelf break. The shelf s.s., represents a sector that experienced the same tectonic of the on-land system. Such a result is confirmed by a good correlation between the depth of marine terraces of erosive origin and eustatic sea level variations recorded for the last $200 \mathrm{ka}$ (Figure 7) that are attributed, for the most part, to 
shallower submarine terraces of the stationing of the Flandrian Transgression (40/46 $\mathrm{m}$ in w.d. - as reported for the offshore of the southern Bulgheria Mount [32]) and the stationing of MIS 3 (50/55 $\mathrm{m}$ and 70/76 $\mathrm{m}$ in w.d.), MIS 5c, and MIS5a (10/15 $\mathrm{m}$ and 18/24 $\mathrm{m}$ in w.d.). In the offshore the Cilento Flysch and Internidi Units, the strong lateral continuity that characterises the terraces located at 47/52 $\mathrm{m}$ in w.d. (Figures $2 \mathrm{~B}$ and 3) suggests that they could also have an origin associated to the Flandrian Transgression.

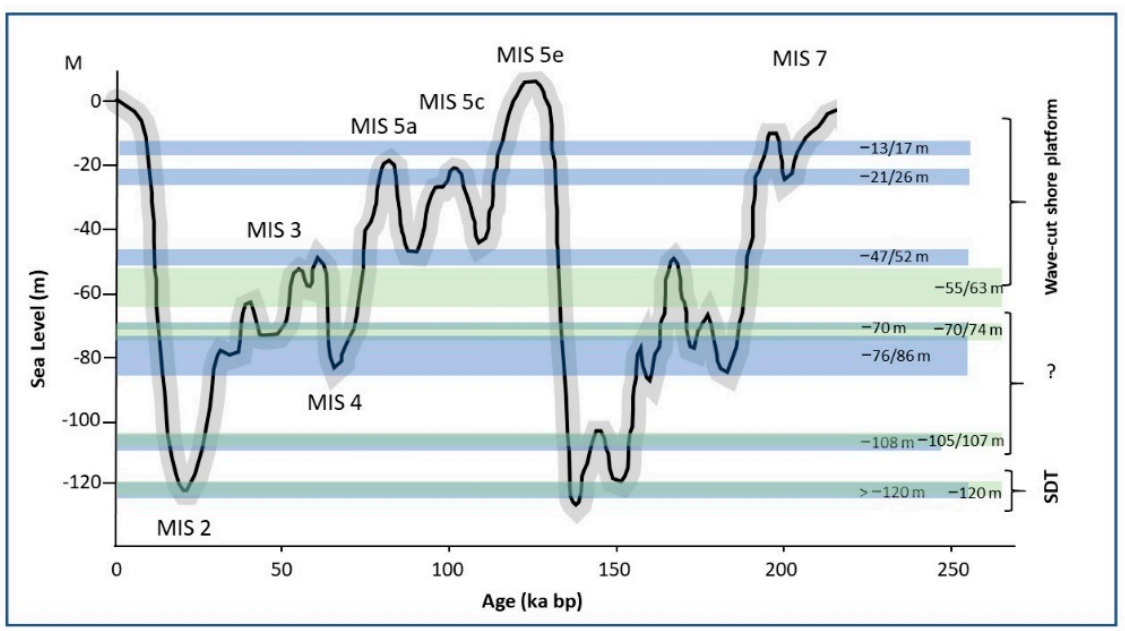

Figure 7. A graph with eustatic sea level variations, expressed in meters, recorded during the last $200 \mathrm{ka} \mathrm{cal}$ (adapted from [76]). Thick horizontal lines indicate major depth intervals where submarine terraced landforms were located in the offshore region of the Cilento Promontory. Different colors refer to different regions as distinguished in Table 2 (light transparent blue for the offshore Cilento Group and Internidi Units, light transparent green for the offshore of the Bulgheria Mount); SDT: Submarine Depositional Terraces.

Sub-aerial marine terraces [7] have, indeed, been traditionally acknowledged to be relevant geomorphological indicators of past sea-level high-stands in regions subjected to tectonic uplift [8]. With time, uplift determines the formation of terraced coastlines, often with a step-like profile, where older terraces are higher and farther from today's coastline [7]. In this work, we focused on understanding the occurrence of paleo, wave-cut shore platforms (forming marine terraces) within the submarine domain [22]. Here, it is important to note that phases of relatively high sea-level or stationary phases during transgressive periods, in the end, determine the most favorable condition for wave-cut shore platform formations on rocky cliffs (because they cause marine processes to prevail over sub-aerial processes). A relative decrease in sea level would, instead, lead to a decrease in the efficiency of marine processes, with the formation of beaches or debris at the base of a cliff, preventing wave-cut shore platform formation. For this reason, wave-cut shore platforms are unlikely to form during low stands or regressive conditions. Therefore, for our study area, we conclude that the occurrence of marine terraces of erosive origin within the submarine domain resulted because shelf s.s. was subjected to the same geodynamics that impacted the Cilento Margin on-land; and because the area was relatively stable during the Upper Pleistocene and, therefore, during earlier high-stand (MIS5c and MIS5a) and stationary periods of the Flandrian Transgression. In contrast, the outer shelf has been lowering, at least since the end of the Lower Pleistocene, and has been involved in the same geodynamics that are altering the Tyrrhenian Basin, promoting the formation of SDTs.

Deeper submarine terraces of erosive origin, as described by [48], at 80/86 m and $100 / 107 \mathrm{~m}$ in w.d., are more difficult to interpret. Therefore, further investigation is required to confirm their actual association to bedrock outcrops.

A higher resolution of the DEM would also lead to a more effective morphometric analysis. The more accurate list of terraced surfaces that would result from the analysis, combined with an adequate reconstruction of late Quaternary environmental conditions 
that controlled formation of wave-cut shore platforms (e.g., wave climatology, as performed in [22]), would provide more precise information to confirm the ascription of the terraces to a defined high-stand period.

\section{Conclusions}

An interesting finding of our study, obtained by coupling terrestrial and submarine terraced landforms [81], is the detection of two main types of submarine terraced landforms in the surveyed sector of the south-eastern Tyrrhenian Margin: (1) erosional terraces (wavecut or abrasion platforms) formed on outcropping bedrock and (2) depositional terraces (i.e., SDTs) generated by late Quaternary depositional sequences. A distinction between the two types of landforms actually depends on a set of parameters dominated by regional geologic settings (the type of bedrock, and geodynamic and sediment inputs) subject to sea-level oscillation. Submarine marine terraces that result from the generation of wave-cut shore platforms were predominantly generated during interglacial periods or during relevant stasis occurring in transgressive events. On the surveyed sector of the south-eastern Tyrrhenian Margin, they formed when bedrock outcrops were exposed on the shelf, making them vulnerable to substantial erosion due to marine processes. Bedrock outcrops also contributed to a disruption of late Quaternary sedimentation on the inner shelf. Based on this evidence, submarine terraces of a strictly erosional nature could not have been formed on a traditional passive margin subject to subsidence. In contrast, subsidence, provides accommodation for the formation of depositional bodies, that according to sediment availability, shelf morphology, and local sea level history provide a suitable condition for a variety of SDTs.

Author Contributions: Conceptualization, M.P., F.R. and A.S.; methodology, V.A.B., A.C. and A.S.; software, V.A.B. and A.S.; investigation, M.P., F.R. and A.C.; data curation, M.P., F.R., V.A.B. and A.S.; writing—original draft preparation, M.P. and F.R. writing—review and editing, A.S., F.R., M.P. and V.A.B.; visualization, V.A.B.; supervision, M.P. and A.S.; project administration, M.P. and A.S.; funding acquisition, A.S. All authors have read and agreed to the published version of the manuscript.

Funding: This article is an outcome of the Project MIUR—Dipartimenti di Eccellenza 2018-2022, Department of Earth and Environmental Sciences, University of Milano-Bicocca.

Institutional Review Board Statement: Not applicable.

Informed Consent Statement: Not applicable.

Data Availability Statement: The bathymetric metadata and Digital Terrain Model data products have been derived from the EMODnet Bathymetry portal—http:/ / www.emodnet-bathymetry.eu (accessed on 20 February 2021). and from http://dati.protezionecivile.it/geoportalDPC/rest/ document\#MagicFoglio10 (accessed on 20 February 2021).

Conflicts of Interest: The authors declare no conflict of interest.

\section{References}

1. International Hydrographic Organization (IHO). Standardization of Undersea Feature Names: Guidelines Proposal form Terminology, 4th ed.; International Hydrographic Organisation(IHO): Monaco City, Monaco; Intergovernmental Oceanographic Commission (IOC): Paris, France, 2008.

2. Jackson, J.A. Glossary of Geology; American Geological Institute: Alexandria, VA, USA, 1997.

3. Chappell, J.M. Geology of coral terraces, Huon Peninsula, New Guinea: A study of Quaternary tectonic movements and sea-level changes. Geol. Soc. Am. Bull. 1974, 85, 553-570. [CrossRef]

4. Penck, A.; Brückner, E. Die Alpen im Eiszeitalter; Tauchnitz: Leipzig, German, 1909; Volume 3, p. 1200.

5. Pirazzoli, P.A. Global sea level changes and their measurement. Glob. Plan. Chang. Lett. 1993, 8, 135-148. [CrossRef]

6. Zazo, G. Interglacial sea levels. Quat. Int. 1999, 55, 101-113. [CrossRef]

7. Pirazzoli, P.A. Marine Terraces. In Encyclopedia of Coastal Science; Schwartz, M.L., Ed.; Encyclopedia of Earth Science Series; Springer: Berlin/Heidelberg, Germany, 2005. Available online: https://doi.org/10.1007/1-4020-3880-1_209 (accessed on 20 February 2021).

8. Selli, R. Il Paleogene nel quadro della Geologia dell'Italia Meridionale. Mem. Soc. Geol. Ital. 1962, 3, 737-790. 
9. Rabineau, M.; Bern e, S.; Olivet, J.L.; Aslanian, D.; Guillocheau, F.; Joseph, P. Paleo sea levels reconsidered from direct observation of paleoshoreline position during Glacial Maxima (for the last 500,000 yr). Earth Planet. Sci. Lett. 2006, 252, 119-137. [CrossRef]

10. Casalbore, D.; Romagnoli, C.; Chiocci, F.; Frezza, V. Morpho-sedimentary characteristics of the volcanic apron around Stromboli volcano. Mar. Geol. 2010, 269, 132-148. [CrossRef]

11. Fraccascia, S.; Chiocci, F.L.; Scrocca, D.; Falese, F. Very high-resolution seismic stratigraphy of Pleistocene eustatic minima markers as a tool to reconstruct the tectonic evolution of the northern Latium shelf (Tyrrhenian Sea, Italy). Geology 2013, 41, 375-378. [CrossRef]

12. Romagnoli, C. Characteristics and morphological evolution of the Aeolian volcanoes from the study of submarine portions. In The Aeolian Islands Volcanoes; Lucchi, F., Peccerillo, A., Keller, J., Tranne, C.A., Rossi, P.L., Eds.; Geological Society: London, UK, 2013; Volume 37, pp. 13-26.

13. Romagnoli, C.; Casalbore, D.; Bosman, A.; Braga, R.; Chiocci, F.L. Submarine structure of Vulcano volcano (Aeolian islands) revealed by high-resolution bathymetry and seismo-acoustic data. Mar. Geol. 2013, 338, 30-45. [CrossRef]

14. Quartau, R.; Hipolito, A.; Romagnoli, C.; Casalbore, D.; Madeira, J.; Tempera, F.; Roque, C.; Chiocci, F.L. The morphology of insular shelves as a key for understanding the geological evolution of volcanic islands: Insights from Ter-ceira Island (Azores). Geochem. Geophys. Geosystems 2014, 15, 1801-1826. [CrossRef]

15. Casalbore, D.; Falese, F.; Martorelli, E.; Romagnoli, C.; Chiocci, F.L. Submarine depositional terraces in the Tyrrhenian Sea as a proxy for paleo-sea level reconstruction: Problems and perspective. Quat. Int. 2020, 544, 1-11. [CrossRef]

16. Micallef, A.; Krastel, S.; Savini, A. Introduction. In Submarine Geomorphology; Micallef, A., Krastel, S., Savini, A., Eds.; Springer: Berlin/Heidelberg, Germany, 2017.

17. Chiocci, F.L.; Orlando, L. Lowstand terraces on Tyrrhenian Sea steep continental slopes. Mar. Geol. 1996, 134, 127-143. [CrossRef]

18. Chiocci, F.L.; D'Angelo, S.; Romagnoli, C. Atlas of submerged depositional terraces along the Italian coasts. Mem. Descr. Della Carta Geol. D'italia 2004, 58, 197.

19. De Pippo, T.; Pennetta, M. Submerged depositional terraces in the Gulf of Policastro (Southern Tyrrhenian sea, Italy). Mem. Descr. Carta Geol. D'italia 2004, 58, 35-38.

20. Sulli, A.; Lo Presti, V. Gasparo Morticelli, M., Antonioli, F.,. Vertical movements in NE Sicily and its offshore: Outcome of tectonic uplift during the last $125 \mathrm{ky}$. Quat. Int. 2013, 288, 168-182. [CrossRef]

21. Pepe, F.; Bertotti, G.; Ferranti, L.; Sacchi, M.; Collura, A.M.; Passaro, S.; Sulli, A. Pattern and rate of post-20 ka vertical tectonic motion around the Capo Vaticano Promontory (W Calabria, Italy) based on offshore geomorphological indicators. Quat. Int. 2014, 322, 85-98. [CrossRef]

22. Bilbao-Lasa, P.; Jara-Muñoz, J.; Pedoja, K.; Álvarez, I.; Aranburu, A.; Iriarte, E.; Galparsoro, I. Submerged Marine Terraces Identification and an Approach for Numerical Modeling the Sequence Formation in the Bay of Biscay (Northeastern Iberian Peninsula). Front. Earth Sci. 2020, 8, 47. [CrossRef]

23. Ricchi, A.; Quartau, R.; Ramalho, R.S.; Romagnoli, C.; Casalbore, D.; Ventura da Cruz, J.; Fradique, C.; Vinhas, A. Marine terrace development on reefless volcanic islands: New insights from high-resolution marine geophysical data offshore Santa Maria Island (Azores Archipelago). Mar. Geol. 2018, 406, 42-56. [CrossRef]

24. Blanc, A.C.; Segre, A.G. Les formations Quaternaires et les gîsements paléolithiques de la côte de Salerno. In Excursion dans les Abruzzes, les Pouilles et sur la cote de Salerne, Procedings of the Actes du IV Congres Internationale du Quaternaire, Roma and Pisa, Italy, August-September 1953; Stanford Library: Stanford, CA, USA, 1956.

25. Lirer, L.; Pescatore, T.; Scandone, P. Livello di piroclastici nei depositi continentali post-Tirreniani del litorale sud-tirrenico. Atti Accad. Gioenia Sci. Nat. Catania 1967, 18, 85-115. (In Italian with English abstract)

26. Baggioni, M. Les côtes du Cilento (Italie du Sud): Morphogénèse littorale actuelle et héritée. Méditerranée 1975, 3, 35-52. (In French with English abstract) [CrossRef]

27. Palma Di Cesnola, A. Il Paleolitico inferiore in Campania. In Proceedings of the 23rd Scientific Meeting, Firenze, Italy, 7-9 May 1980; Istituto Italiano di Preistoria e Protostoria: Firenze, Italy, 1982; pp. 207-224.

28. Brancaccio, L.; Cinque, A.; Russo, F.; Belluomini, G.; Branca, M.; Delitala, L. Segnalazione e datazione di depositi marini tirreniani sulla costa campana. Boll. Soc. Geol. Ital. 1990, 109, 259-265. (In Italian with English abstract)

29. Romano, P. La distribuzione dei depositi marini pleistocenici lungo le coste della Campania. Stato delle conoscenze e prospettive di ricerca. Studi Geol. Camerti N. Sp. 1992, 1, 265-269. (In Italian with English abstract)

30. Cinque, A.; Romano, P.; Rosskopf, C.; Santangelo, N.; Santo, A. Morfologie costiere e depositi quaternari tra Agropoli e Ogliastro Marina (Cilento, Italia meridionale). Il Quat. 1994, 7, 3-16. (In Italian with English abstract)

31. Russo, F. Segnalazione di un livello fossilifero riferibile al Tirreniano a Cala Bianca (Marina di Camerota). Mem. Descr. Carta Geol. D'italia 1994, 52, 395-398. (In Italian with English abstract)

32. Antonioli, F.; Cinque, A.; Ferranti, L.; Romano, P. Emerged and submerged quaternary marine terraces of Palinuro Cape (southern Italy). Mem. Descr. Carta Geol. D'italia 1994, 52, 237-260.

33. Ascione, A.; Romano, P. Vertical movements on the eastern margin of the Tyrrhenian extensional basin. New data from Mt Bulgheria (Southern Appenines, Italy). Tectonophysics 1999, 315, 337-358. [CrossRef]

34. Esposito, C.; Filocamo, F.; Marciano, R.; Romano, P.; Santangelo, N.; Scarciglia, F.; Tuccimei, P. Late Quaternary shorelines in Southern Cilento (Mt. Bulgheria): Morphostratigraphy and chronology. Il Quat. It. J. Quater. Sci. 2003, 16, 3-14. 
35. Guida, D.; Valente, A. Terrestrial and marine landforms along the Cilento coastland (Southern Italy): A framework for landslide hazard assessment and environmental conservation. Water 2019, 11, 2618. [CrossRef]

36. Bartole, R.; Savelli, C.; Tramontana, M.; Wezel, F.C. Structural and sedimentary features in the Tyrrhenian margin off Campania, Southern Italy. Mar. Geol. 1984, 55, 163-180. [CrossRef]

37. Cinque, A.; Patacca, E.; Scandone, P.; Tozzi, M. Quaternary kinematic evolution of the southern Apennines. Relationships between surface geological features and deep lithospheric structures. Ann. Geof. 1993, 36, 249-259.

38. Casciello, E.; Cesarano, M.; Pappone, G. Extensional detachment faulting on the Tyrrhenian margin of the southern Apennines contractional belt (Italy). J. Geol. Soc. 2006, 163, 617-629. [CrossRef]

39. Cammarosano, A.; Danna, M.; De Rienzo, F.; Martelli, L.; Miele, F.; Nardi, G. Il substrato del Gruppo del Cilento tra il M. Vesole e il M. Sacro (Cilento, Appennino Meridionale). Boll. Soc. Geol. Ital. 2000, 119, 395-405, (In Italian with English abstract).

40. Cammarosano, A.; Cavuoto, G.; Danna, M.; De Capoa, P.; De Rienzo, F.; Di Staso, A.; Giardino, S.; Martelli, L.; Nardi, G.; Sgrosso, A. Nuovi dati e nuove interpretazioni sui flysch terrigeni del Cilento (Appennino meridionale, Italy). Boll. Soc. Geol. Ital. 2004, 123, 253-273. (In Italian with English abstract)

41. Amore, F.O.; Bonardi, G.; Ciampo, G.; De Capoa, P.; Perrone, V.; Sgrosso, I. Relazioni tra flysch Interni e domini appenninici: Reinterpretazione delle formazioni di Pollica, S. Mauro e Albidona e l'evoluzione infra-medio miocenica delle zone esterne sudappenniniche. Mem. Soc. Geol. Ital. 1988, 41, 285-297. (In Italian with English abstract)

42. Bonardi, G.; Amore, F.O.; Ciampo, G.; De Capoa, P.; Miconnet, P.; Perrone, V. Il Complesso Liguride Auct.: Stato delle conoscenze e problemi aperti sulla sua evoluzione pre-appenninica ed i suoi rapporti con I'Arco Calabro. Mem. Soc. Geol. Ital. 1988, 41, 7-35. (In Italian with English abstract)

43. Zuppetta, A.; Mazzoli, S. Deformation history of a synorogenic sedimentary wedge, northern Cilento area, southern Apennines thrust and fold belt, Italy. Geol. Soc. Am. Bull. 1997, 109, 698-708. [CrossRef]

44. Ciarcia, S.; Vitale, S.; Di Staso, A.; Iannace, A.; Mazzoli, S.; Torre, M. Stratigraphy and tectonics of an Internal Unit of the southern Apennines: Implications for the geodynamic evolution of the peri-Tyrrhenian mountain belt. Terra Nova 2009, 21, 88-96. [CrossRef]

45. Cocco, E. Note Illustrative della Carta Geologica d'Italia alla Scala 1:100.000. Foglio 209 Vallo della Lucania; Servizio Geologico d'Italia: Rome, Italy, 1971; p. 45.

46. Cieszkowski, M.; Oszczypko, N.; Pescatore, T.S.; Slaczka, A.; Senatore, M.R. Megatorbiditi calcareo-marnose nelle successioni flyscioidi dell'Appennino Meridionale (Cilento, Italia) e dei Carpazi Settentrionali (Polonia). Boll. Soc. Geol. Ital. 1995, 114, 67-88. (In Italian with English abstract)

47. D'Argenio, B.; Pescatore, T.S.; Scandone, P. Schema geologico dell'Appennino Meridionale (Campania e Lucania). Atti Accad. Naz. Lincei 1973, 183, 49-72.

48. Ferraro, L.; Pescatore, T.; Russo, B.; Senatore, M.R.; Vecchione, C.; Coppa, M.G.; Di Tuoro, A. Studi di geologia marina del margine tirrenico: La piattaforma continentale tra Punta Licosa e Capo Palinuro (Tirreno meridionale). Boll. Soc. Geol. Ital. 1997, 116, 473-485. (In Italian with English abstract)

49. Kastens, K.; Mascle, J.; Auroux, C.; Bonatti, E.; Broglia, C.; Channel, J.; Curzi, P.; Emeis, K.; Glacon, G.; Hasegawa, S.; et al. ODP Leg 107 in the Tyrrhenian sea: Insights into passive margin and back-arc basin evolution. Geol. Soc. Am. Bull. 1988, 100, 1140-1156. [CrossRef]

50. Trincardi, F.; Field, M.E. Geometry, lateral variation and preservation of downlapping regressive shelf deposits: Eastern Tyrrhenian Sea margin, Italy. J. Sediment. Petrol. 1991, 61, 775-790.

51. Pennetta, M. Margine tirrenico meridionale: Morfologia e sedimentazione tardo pleistocenica-olocenica del sistema di piattaformascarpata. Boll. Soc. Geol. Ital. 1996, 115, 339-354. (In Italian with English abstract)

52. Pennetta, M. Evoluzione morfologica quaternaria del margine tirrenico sud-orientale tra Capo Palinuro e Capo Bonifati. Il Quat. 1996, 9, 353-358. (In Italian with English abstract)

53. Budillon, F.; Conforti, A.; Tonielli, R.; De Falco, G.; Di Martino, G.; Innangi, S.; Marsella, E. The Bulgheria canyon-fan: A small-scale proximal system in the eastern Tyrrhenian Sea (Italy). Mar. Geophys. Res. 2011, 32, 83-97. [CrossRef]

54. De Pippo, T.; Pennetta, M. Late Quaternary morphological evolution of a continental margin based on emerged and submerged morphostructural features: The south-eastern Tyrrhenian margin (Italy). Zeit. Geomorph. N. F. 2000, 44, 435-448.

55. Aiello, G. Elaborazione ed interpretazione geologica di sismica di altissima risoluzione nell'offshore del promontorio del Cilento (Tirreno meridionale, Italia). Quad. Geof. 2019, 155, 7-19. (In Italian with English abstract)

56. Alessio, M.; Allegri, F.; Antonioli, F.; Belluomini, G.; Ferranti, L.; Improta, S.; Manfra, L.; Proposito, A. Risultati preliminari relativi alla datazione di speleotemi sommersi nelle fasce costiere del Tirreno centrale. G. Di Geol. 1992, 54, 165-193. (In Italian with English abstract)

57. Senatore, M.R. Terrazzi deposizionali sommersi al largo di Punta Licosa. Mem. Descr. Carta Geol. D'italia 2004, 58, 153-154. (In Italian with English abstract)

58. Savini, A.; Basso, D.; Bracchi, V.A.; Corselli, C.; Pennetta, M. Maerl-bed mapping and carbonate quantification on submerged terraces offshore the Cilento promontory (Tyrrhenian Sea, Italy). Geodiversitas 2012, 34, 77-98. [CrossRef]

59. Posamentier, H.W.; Jervey, M.T.; Vail, P.R. Eustatic control on clastic deposition. I. conceptual framework. Sepm Sp. Publ. 1988, 42, 109-124. 
60. Swift, D.J.P.; Stanley, D.J.; Curray, J.R. Relict sediments on continental shelf: A reconsideration. J. Geol. 1971, 79, 322-346. [CrossRef]

61. Sgrosso, I.; Ciampo, G. Sulla presenza di terreni calabriani nei dintorni di Camerota. Boll. Soc. Natur. Napoli 1966, 75, 561-587. (In Italian with English abstract)

62. Baggioni, M. Le Mont Bulgheria (Italie méridionale): Morphologie littorale et néotectonique. Méditerranée 1978, 32, 33-46. (In French with English abstract) [CrossRef]

63. Baggioni, M.; Suc, J.P.; Vernet, J.L. Le Plio-Pleistocene du Camerota (Italie meridionale): Geomorphologie et paleoflores. Geobios 1981, 14, 229-237. (In French with English abstract) [CrossRef]

64. Borrelli, A.; Ciampo, G.; De Falco, M.; Guida, D.; Guida, M. La morfogenesi del Monte Bulgheria (Campania) durante il Pleistocene inferiore e medio. Mem. Soc. Geol. Ital. 1988, 41, 667-672. (In Italian with English abstract)

65. Brancaccio, L.; Cinque, A.; Romano, P.; Rosskopf, C.; Russo, F.; Santangelo, N. L'evoluzione delle pianure costiere della Campania: Geomorfologia e neotettonica. Mem. Soc. Geogr. Ital. 1995, 53, 313-336. (In Italian with English abstract)

66. Iannace, A.; Romano, P.; Santangelo, N.; Santo, A.; Tuccimei, P. The OIS 5c along Licosa Cape promontory (Campania region, Southern Italy): Morphostratigraphy and U/Th dating. Zeit. Geomorph. N. F. 2001, 45, 307-319.

67. Marciano, R.; Munno, R.; Petrosino, P.; Santangelo, N.; Santo, A.; Villa, I. Late quaternary tephra layers along the Cilento coastline (southern Italy). J. Volcan Geotherm. Res. 2008, 177, 227-243. [CrossRef]

68. Gambassini, P.; Ronchitelli, A. Linee di sviluppo dei complessi del Paleolitico inferiore-Medio nel Cilento. Riv. Sc. Preist. 1998, 49, 357-376. (In Italian with English abstract)

69. Baggioni-Lippmann, M. Néotectonique et géomorphologie dans l'Apennin campanien (Italie méridionale). Rev. Géol. Dynam. Géogr. Phys. 1981, 23, 41-54. (In French with English abstract)

70. Marani, M.; Tavani, M.; Trincardi, F.; Argnani, A.; Borsetti, A.M.; Zitellini, N. Pleistocene progradation and postglacial events of the NE Tyrrhenian continental shelf between the Tiber river delta and Capo Circeo. Mem. Soc. Geol. Ital. 1988, 36, 67-89.

71. Pranzini, E. La Forma Delle Coste; Zanichelli: Modena, Italy, 2004.

72. Savini, A.; Pennetta, M.; Corselli, C. Geophysical Investigation for exploring marine sand deposits (Cilento Peninsula-Southern Italy). In Proceedings of the Seventh International Conference on Mediterranean Coastal Environment, MEDCOAST 05, Kusadasi, Turkey, 24-29 October 2005; Volume 2, pp. 973-984.

73. Ferranti, L.; Antonioli, F.; Mauz, B.; Amorosi, A.; Dai Pra, G.; Mastronuzzi, G.; Monaco, C.; Orrù, P.; Pappalardo, M.; Radtke, U.; et al. Markers of the last interglacial sea level high stand along the coast of Italy: Tectonic implications. Quat. Int. 2006, 145, 30-54. [CrossRef]

74. Budetta, P.; Santo, A.; Vivenzio, F. Landslide hazard mapping along the coastline of Cilento region (Italy) by means of a GIS-based parameter rating approach. Geomorphology 2008, 94, 340-352. [CrossRef]

75. Moore, W.S. Late Pleistocene sea level history. In Uranium Series Disequilibrium: Application to Environmental Problems; Ivanovich, M., Harmon, R.S., Eds.; Oxford University Press: Oxford, UK, 1982.

76. Waelbroeck, C.; Labeyrie, L.; Michel, E.; Duplessy, J.; McManu, J.; Lambeck, K.; Balbon, E.; Labracherie, M. Sea-level and deep water temperature changes derived from benthic foraminifera isotopic records. Quat. Sci. Rev. 2002, 21, 295-305. [CrossRef]

77. Martinson, D.G.; Pisias, N.G.; Hays, J.D.; Imbrie, J.; Moore, T.C.; Shackleton, N.J. Age dating and the orbital theory of the ice ages: Development of a high-resolution 0 to 300.000 year chronostratigraphy. Quat. Res. 1987, 27, 1-29. [CrossRef]

78. Lambeck, K.; Rouby, H.; Purcell, A.; Sun, Y.; Sambridge, M. Sea level and global ice volumes from the Last Glacial Maximum to the Holocene. Proc. Natl. Acad. Sci. USA 2014, 111, 15296-15303. [CrossRef] [PubMed]

79. Benjamin, J.; Rovere, A.; Fontana, A.; Furlani, S.; Vacchi, M.; Inglis, R.H.; Galili, E.; Antonioli, F.; Sivan, D.; Miko, S.; et al. Late Quaternary sea-level changes and early human societies in the central and eastern Mediterranean Basin: An interdisciplinary review. Quat. Int. 2017, 449, 29-57. [CrossRef]

80. Rovere, A.; Raymo, M.E.; Vacchi, M.; Lorscheid, T.; Stocchi, P.; Gómez-Pujol, L.; Harris, D.L.; Casella, E.; O’Leary, M.J.; Hearty, P.J. The analysis of Last Interglacial (MIS 5e) relative sea-level indicators: Reconstructing sea-level in a warmer world. Earth Sci. Rev. 2016, 159, 404-427. [CrossRef]

81. Prampolini, M.; Savini, A.; Foglini, F.; Soldati, M. Seven Good Reasons for Integrating Terrestrial and Marine Spatial Datasets in Changing Environments. Water 2020, 12, 2221. [CrossRef] 